\title{
Peningkatan Kualitas Biourin Sapi dengan Penambahan Pupuk Hayati dan Molase serta Pengaruhnya terhadap Pertumbuhan dan Produktivitas Pakchoy
}

\author{
Improving the Quality of Cow Biorine with Addition of Biofertilizer and Molasses \\ and Effect on Growth and Productivity of Pakchoy
}

\author{
Yulia Nuraini $^{* *}$ dan Rurin Eka Asgianingrum
}

Diterima 17 Mei 2017/Disetujui 25 Oktober 2017

\begin{abstract}
The use of inorganic fertilizers to increase crop productivity can be suppressed by switching it to organic fertilizers. The abundance of cow urine waste can be used as organic fertilizer and to be used as biourine. This study was aimed at determining the effect of biofertilizers and molasses toward biourine quality and its effect on productivity of pakchoy. This research was conducted in UPT Compost Brawijaya University, and glasshouses in Sukapura Village, Probolinggo in August to November 2016. This research consisted of two steps. First production of biourine with the addition of organic material such as molasses, biofertilizers, and empon-empon namely turmeric, galangal, and Kaempferia galanga, which consists of 12 treatments with 3 replications arranged in a completely randomized design, and application of biourine on pakchoy consisting of 6 treatments (control, doses of 200, 300, 400, 500, and $600 \mathrm{ml} \mathrm{L}^{-1}$ ) with three replications. The results of first step showed E1 treatment (10 L biourine $+30 \mathrm{ml}+750 \mathrm{ml}$ molasses) can improve $\mathrm{N}$-total $860 \%$, organic matter 282\%, and population of microbe 1229\%. The best biourine in first research (E1 treatment) was applied with dose $600 \mathrm{ml} \mathrm{L}^{-1}$ showed the best result. It showed to increase the number of leaves as much as $48 \%$ and the fresh weight of pakchoy by $405 \%$ when compared to no biourine treatment.
\end{abstract}

Keywords: biofertilizer, inceptisols, soil health, and population of microbe

\begin{abstract}
ABSTRAK
Penggunaan pupuk anorganik untuk meningkatkan produktivitas tanaman dapat ditekan dengan beralih menggunakan pupuk organik. Melimpahnya limbah urin sapi dapat dimanfaatkan sebagai pupuk organik dengan dijadikan biourin. Penelitian ini bertujuan untuk mengetahui pengaruh penambahan pupuk hayati dan molase terhadap kualitas biourin dan pengaruhnya terhadap produktivitas pakchoy. Penelitian dilakukan di UPT Kompos Universitas Brawijaya, dan rumah kaca di Desa Sukapura, Probolinggo pada bulan Agustus sampai Nopember 2016. Penelitian dilakukan dalam 2 tahap, pertama pembuatan biourin dengan penambahan bahan organik berupa molase, pupuk hayati, dan empon-empon (kunyit, lengkuas, dan kencur) yang terdiri dari 12 taraf perlakuan dengan 3 ulangan pada Rancangan Acak Lengkap, dan kedua pengaplikasian biourin pada tanaman pakchoy yang terdiri dari 6 taraf perlakuan (kontrol, dosis 200, 300, 400, 500, dan $600 \mathrm{ml} \mathrm{L}^{-1}$ ) dengan 3 kali ulangan. Hasil penelitian tahap pertama menujukkan perlakuan E1 (10 L urin $+30 \mathrm{ml}$ pupuk hayati $+750 \mathrm{ml}$ molase) mampu meningkatkan $\mathrm{N}$-total $860 \%$, bahan organik $282 \%$, dan populasi mikroba sebesar $1229 \%$. Aplikasi biourin terbaik pada penelitian tahap 1 (perlakuan E1) dengan dosis $600 \mathrm{ml} \mathrm{L}^{-1}$ pada tanaman pakchoy menunjukkan hasil terbaik, ditunjukkan dengan meningkatnya jumlah daun sebanyak $48 \%$ dan bobot basah tanaman sebesar $405 \%$ jika dibandingkan tanpa pemberian biourin.
\end{abstract}

Kata kunci: inceptisol, kesuburan tanah, mikroba, dan pupuk organik cair

${ }^{1}$ Jurusan Tanah, Fakultas Pertanian Universitas Brawijaya

Jl. Veteran, Malang 65145, No Telp. 0341-553623/08123300379,

email: yulianuraini@yahoo.com (*penulis korespondensi) 


\section{PENDAHULUAN}

Penggunaan pupuk anorganik yang berlebihan menyebabkan beberapa masalah pada tanah dan dapat mencemari air sehingga keseimbangan alam menjadi terganggu (Indriani, 2011). Penggunaan pupuk anorganik untuk meningkatkan produktivitas tanaman dapat ditekan dengan beralih menggunakan pupuk organik. Limbah cair pada peternakan sapi yang berupa urin kurang dimanfaatkan, sehingga dapat mencemari lingkungan. Setiap harinya satu ekor sapi mampu menghasilkan kurang lebih 5 liter urin. Urin sapi yang melimpah berpotensi untuk dijadikan sebagai pupuk organik berupa biourin. Biourin ialah pupuk cair yang mengandung unsur yang lengkap yaitu nitrogen, fosfor, dan kalium dalam jumlah yang sedikit serta seng, besi, mangan, dan tembaga. Biourin dapat memberikan peningkatan hasil tanaman yang hampir menyamai bahan penyubur tanaman (BPT) (Perdana, 2015). Kurniadinata (2007), menyatakan bahwa penggunaan urin sapi sebagai pupuk organik akan memberikan keuntungan diantaranya harga relatif murah, mudah didapat dan diaplikasikan, serta memiliki kandungan hara yang dibutuhkan tanaman. Pupuk urin sapi mengandung hormon tertentu yang dapat merangsang perkembangan tanaman dan mengandung lebih banyak $\mathrm{N}$ dan $\mathrm{K}$ dibandingkan dengan pupuk kandang sapi padat (Aisyah et al., 2011). Urin sapi dapat dimanfaatkan sebagai pupuk biourin dengan cara menginkubasinya terlebih dahulu hingga terdekomposisi.

Pada proses dekomposisi urin sapi ditambahkan lengkuas, kencur, kunyit, temulawak dan jahe. Bau urin sapi diharapkan dapat dinetralisir dengan minyak atsiri yang terkandung dalam empon-empon (Tandi et al., 2015). Minyak atsiri tersusun atas eugenol (Kartika et al., 2016), yang berfungsi sebagai antimikroba (Nurawaliyah, 2014), sehingga mikroba anaerob dalam proses pengomposan dapat berkurang. Berkurangnya mikroba anaerob ini menyebabkan berkurangnya bau pada biourin.

Pakchoy merupakan tanaman sayuran yang mudah ditanam dan dapat tumbuh dengan baik pada segala musim (Haryanto et al., 2007).
Salah satu faktor budidaya yang penting dalam menunjang produktivitas tanaman pakchoy ialah pemupukan. Masalah yang umum dalam pemupukan adalah rendahnya efisiensi serapan hara oleh tanaman (Ohorella, 2012). Tanaman pakchoy lebih banyak membutuhkan nitrogen (N) dalam jumlah banyak untuk menunjang pembentukan organ vegetatifnya seperti daun, sehingga untuk meningkatkan produksi pakchoy perlu ditambahkan pupuk dengan kandungan N yang tinggi (Sufianto, 2014). Hasil penelitian Rizki et al. (2014) menunjukkan, pemberian biourin dengan dosis $400 \mathrm{ml} \mathrm{L}^{-1}$ dapat meningkatkan pertumbuhan dan produksi sawi hijau (Brassica rafa) dibandingkan tanpa diberikan biourin sapi. Berdasarkan uraian diatas, penelitian ini ditujukan untuk mengetahui pengaruh penambahan pupuk hayati dan molase terhadap kualitas biourin berdasarkan indikator biologi dan kimia serta pengaruhnya terhadap produktivitas tanaman pakchoy (Brassica rapa var. Parachinensis).

\section{METODE PENELITIAN}

\section{Waktu dan Lokasi Penelitian}

Penelitian dilakukan pada Bulan Agustus sampai November 2016. Pembuatan biourin dilakukan di Unit Pelayanan Terpadu (UPT) Kompos, Universitas Brawijaya Malang, sedangkan penanaman pakchoy di rumah kaca Desa Sukapura, Probolinggo, analisa sifat kimia biourin dan analisis total mikroba dilaksanakan di Laboratorium Jurusan Tanah Fakultas Pertanian Universitas Brawijaya.

\section{Rancangan Penelitian dan Variabel Pengamatan}

Pembuatan biourin sapi terdiri atas 12 taraf perlakuan (Tabel 1) yang disusun dalam Rancangan Acak Lengkap dengan tiga kali ulangan, sedangkan pengaplikasian biourin pada tanaman pakchoy terdiri atas 6 taraf perlakuan (Tabel 2) dengan 3 kali ulangan yang disusun dalam Rancangan Acak Kelompok (RAK). 
Tabel 1. Kombinasi perlakuan pembuatan biourin sapi

\begin{tabular}{|c|c|c|}
\hline No & Kode & Konsentrasi Pupuk Hayati dan Molase \\
\hline 1 & Kontrol 1 & $10 \mathrm{~L}$ urin sapi \\
\hline 2 & Kontrol 2 & $10 \mathrm{~L}$ urin sapi + empon-empon $500 \mathrm{ml}$ \\
\hline 3 & A1 & $10 \mathrm{~L}$ urin sapi $+10 \mathrm{ml}$ Pupuk hayati \\
\hline 4 & A2 & $10 \mathrm{~L}$ urin sapi + $10 \mathrm{ml}$ Pupuk hayati + empon-empon $500 \mathrm{ml}$ \\
\hline 5 & B1 & $10 \mathrm{~L}$ urin sapi + $500 \mathrm{ml}$ molase \\
\hline 6 & B2 & $10 \mathrm{~L}$ urin sapi + $500 \mathrm{ml}$ molase + empon-empon $500 \mathrm{ml}$ \\
\hline 7 & $\mathrm{C} 1$ & $10 \mathrm{~L}$ urin sapi + $10 \mathrm{ml}$ pupuk hayati + $250 \mathrm{ml}$ molase \\
\hline 8 & $\mathrm{C} 2$ & $10 \mathrm{~L}$ urin sapi $+10 \mathrm{ml}$ pupuk hayati $+250 \mathrm{ml}$ molase + empon-empon $500 \mathrm{ml}$ \\
\hline 9 & D1 & $10 \mathrm{~L}$ urin sapi $+20 \mathrm{ml}$ pupuk hayati $+500 \mathrm{ml}$ molase \\
\hline 10 & D2 & $10 \mathrm{~L}$ urin sapi $+20 \mathrm{ml}$ pupuk hayati $+500 \mathrm{ml}$ molase + empon-empon $500 \mathrm{ml}$ \\
\hline 11 & E1 & $10 \mathrm{~L}$ urin sapi $+30 \mathrm{ml}$ pupuk hayati $+750 \mathrm{ml}$ molase \\
\hline 12 & E2 & $10 \mathrm{~L}$ urin sapi $+30 \mathrm{ml}$ pupuk hayati $+750 \mathrm{ml}$ molase + empon-empon $500 \mathrm{ml}$ \\
\hline
\end{tabular}

Variabel yang diamati pada penelitian ini adalah total mikroba, total $E$. coli, dan Salmonella $s p, \mathrm{pH}, \mathrm{C}$-organik, N total, $\mathrm{P}, \mathrm{K}$, rasio $\mathrm{C} / \mathrm{N}$, jumlah daun dan bobot basah pakchoy serta sifat kimia tanah, yang meliputi $\mathrm{pH}, \mathrm{C}$-organik, $\mathrm{N}$ total, $\mathrm{P}, \mathrm{K}$, dan rasio $\mathrm{C} / \mathrm{N}$. Data yang diperoleh dianalisis dengan menggunakan ANOVA 5\% dan apabila terdapat perbedaan nyata antar parameter dilakukan uji lanjut dengan beda nyata jujur (BNJ) $5 \%$.

\section{Pengambilan Urin Sapi dan Pembuatan Biourin}

Urin sapi diperoleh dari peternak sapi di Desa Putut Pandansari, Ngantang, Malang yang dikumpulkan sebanyak 1000 liter. Urin sapi dimasukkan ke dalam jerigen dengan masing-masing jerigen diisi urin sebanyak 10 L. Kemudian ditambahkan pupuk hayati yang menggandung mikroba (Fastdec) (Tabel 3) dan molase dengan dosis sesuai pada Tabel 1. Urin sapi di dalam jerigen kemudian diberi selang aerator untuk menjaga sirkulasi udara selama proses dekomposisi.

\section{Pemeliharaan dan Aplikasi Pupuk Biourin}

Pemeliharaan dilakukan dengan mengecek selang aerator dan mengaduk urin. Biourin dengan kualitas terbaik, dilihat dari kandungan hara, aroma dan bau serta jumlah mikroba kemudian diaplikasikan ke tanaman pakchoy pada dosis yang berbeda sesuai dengan Tabel 2. Pupuk biourin diberikan secara bertahap. Biourin yang telah diencerkan diaplikasikan ke tanaman pada minggu ke-1, 2, dan 3 setelah tanam disesuaikan dengan perlakuan yang ada pada Tabel 2 .

\section{Penanaman dan Pemeliharaan Tanaman Pakchoy}

Benih pakchoy disemai selama 21 hari sebelum ditanam di polibag. Pemeliharaan tanaman pakchoy meliputi penyiraman dan pengendalian hama penyakit dengan menggunakan metode fisik (manual).

\section{HASIL DAN PEMBAHASAN}

\section{Karakteristik Tanah dan Bahan yang Digunakan dalam Pembuatan Biourin}

Tanah yang digunakan diambil dari Desa Sukapura, Kecamatan Sukapura, Probolinggo dengan jenis tanah Inceptisol, yaitu tanah muda yang berkembang dengan kandungan unsur hara yang masih rendah. Hasil analisis tanah inceptisol menunjukkan $\mathrm{pH}$ tanah yang bereaksi masam, kandungan bahan organik tanah yang sangat rendah begitu pula dengan total populasi mikroba. Kondisi hara tanah inceptisol sangat kurang untuk menunjang kebutuhan tanaman. Oleh karena itu, budidaya tanaman pada tanah inceptisols perlu diimbangi dengan masukan pupuk dari luar.

Hasil analisis kandungan hara dan mikroba menunjukkan, urin sapi yang digunakan memiliki $\mathrm{pH}$ yang basa (Tabel 3), dengan $\mathrm{C} / \mathrm{N}$ rasio rendah, populasi mikroba rendah, serta $E$. coli dan Salmonella $s p$ rendah.Bahan lain seperti molase, pupuk 
hayati dan Empon-empon memiliki $\mathrm{pH}$ yang tergolong asam dengan nilai berturut-turut 4.9; 3.6; dan 4.3, sedangkan kadar $\mathrm{C} / \mathrm{N}$ rasio ketiga bahan tersebut tergolong sangat tinggi. Populasi mikroba pada empon-empon dan molase tergolong rendah (Tabel 3) sedangkan pada pupuk hayati populasi mikroba termasuk sedang (Tabel 3).

\section{Pengaruh Kombinasi Molase, Pupuk Hayati, dan Empon-Empon terhadap Status Hara Biourin}

Perlakuan memberikan pengaruh yang nyata berdasarkan uji ANOVA pada taraf 5\%, terhadap semua parameter pengamatan pada 28 hari setelah dekomposisi. Hasil penelitian menunjukkan kadar C-organik, N-total, C/N rasio dan bahan organik mengalami penurunan di hari ke-28 setelah dekomposisi, sedangkan $\mathrm{pH}, \quad$ P-total dan N-total mengalami peningkatan (Tabel 4). Perbedaan status hara disebabkan oleh lama waktu dekomposisi. Hal ini sesuai dengan pernyataan Rinekso (2011), bahwa lama waktu yang digunakan dalam proses dekomposisi akan mempengaruhi kandungan C-organik, N, P, dan K. Penurunan hara diduga karena proses dekomposisi yang terjadi terlalu lama, sehingga aktifitas mikroba telah berkurang.

Kontrol memiliki $\mathrm{pH}$ yang paling tinggi yaitu sebesar 8 dan berbeda nyata dibandingkan dengan perlakuan lainnya pada uji BNJ taraf 5\%, hal ini dikarenakan pada analisis dasar urin sapi $\mathrm{pH}$ urin sapi memiliki pH sebesar 8.1 (Tabel 4). Bahan-bahan yang digunakan untuk campuran biourin akan berpengaruh pada kandungan biourin tersebut, hal tersebut terjadi pada perlakuan E1 (30 ml pupuk hayati dan $750 \mathrm{ml}$ molase pada $10 \mathrm{~L}$ urin) yang memiliki $\mathrm{pH}$ paling rendah, hal ini dikarenakan pada perlakuan E1 komposisi bahan campurannya paling tinggi, dan bahan campuran tersebut memikili $\mathrm{pH}$ yang masam. Penurunan $\mathrm{pH}$ juga disebabkan karena adanya aktifitas dekomposisi yang lebih cepat oleh mikroba sehingga $\mathrm{pH}$ menjadi masam.

Perlakuan memberikan pengaruh yang nyata terhadap kadar bahan organik pada biourin berdasarkan uji ANOVA pada taraf $5 \%$. Kadar bahan organik tertinggi terdapat pada perlakuan E1 (30 ml pupuk hayati dan $750 \mathrm{ml}$ molase pada $10 \mathrm{~L}$ urin) dan berbeda nyata berdasarkan uji BNJ 5\% bila dibandingkan dengan perlakuan lain. Tingginya kadar bahan organik pada perlakuan E1 diduga dipengaruhi oleh penambahan molase. Tingginya bahan organik akan dapat meningkatkan kulitas pupuk yang dihasilkan. Penambahan molase yang mengandung bahan organik dapat meningkatkan kualitas pupuk. Meskipun demikian, Kandungan kimia biourin (kecuali pH) setiap perlakuan pada hari ke-28 dekomposisi belum memenuhi standar minimal pupuk organik cair.

Tabel 2. Dosis aplikasi biourin pada tanaman pakchoy

\begin{tabular}{ccc}
\hline No & Kode & Keterangan* \\
\hline 1 & P0 & Tanpa pengaplikasian pupuk biourin \\
2 & P1 & Dengan pengaplikasian pupuk biourin sebanyak $200 \mathrm{ml} \mathrm{L}^{-1}$ \\
3 & P2 & Dengan pengaplikasian pupuk biourin sebanyak $300 \mathrm{ml} \mathrm{L}^{-1}$ \\
4 & P3 & Dengan pengaplikasian pupuk biourin sebanyak $400 \mathrm{ml} \mathrm{L}^{-1}$ \\
5 & P4 & Dengan pengaplikasian pupuk biourin sebanyak $500 \mathrm{ml} \mathrm{L}^{-1}$ \\
6 & P5 & Dengan pengaplikasian pupuk biourin sebanyak $600 \mathrm{ml} \mathrm{L}^{-1}$
\end{tabular}

Keterangan: *digunakan dalam polibag berisi tanah $5 \mathrm{~kg}$ dan dosis untuk pertanaman.

Tabel 3. Kandungan hara dan mikroba dalam bahan pembuatan biourin

\begin{tabular}{|c|c|c|c|c|}
\hline Parameter & Urin Sapi & Molase & Fastdec & Empon-empon \\
\hline $\mathrm{pH}$ & $8.1 \quad(\mathrm{AB})$ & $4.9 \quad(\mathrm{M})$ & $3.6 \quad(\mathrm{SM})$ & $4.3 \quad(\mathrm{SM})$ \\
\hline C/N Ratio & $3 \quad(\mathrm{SR})$ & $63 \quad(\mathrm{ST})$ & $(\mathrm{ST})$ & $(\mathrm{ST})$ \\
\hline Populasi Mikroba (cfu/ml) & $15 \times 10^{4}(\mathrm{R})$ & $16 \times 10^{4}(\mathrm{R})$ & $54 \times 10^{7}(\mathrm{~S})$ & $40 \times 10^{2}(\mathrm{R})$ \\
\hline Populasi E. coli $(\mathrm{cfu} / \mathrm{ml})$ & $19 \times 10^{3}(\mathrm{R})$ & 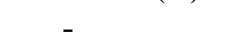 & 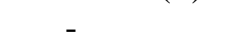 & $+2+2+2+2$ \\
\hline $\begin{array}{l}\text { Popuasi Salmonella sp. } \\
(\mathrm{cfu} / \mathrm{ml})\end{array}$ & $20 \times 10^{4}(\mathrm{R})$ & - & - & - \\
\hline
\end{tabular}

Keterangan: Sumber Kriteria Balittan, 2009. AB (agak basa), SM (sangat masam), M (masam), SR (sangat rendah), R (rendah), S (sedang), ST (sangat tinggi). (-) = tidak diamati. 
Tabel 4. Kandungan kimia biourin pada 28 hari dekomposisi

\begin{tabular}{ccccccccc}
\hline No & Perlakuan & $\mathrm{pH}$ & $\begin{array}{c}\text { Bahan } \\
\text { Organik } \\
(\%)\end{array}$ & $\begin{array}{c}\text { C- } \\
\text { Organik } \\
(\%)\end{array}$ & $\begin{array}{c}\text { N-total } \\
(\%)\end{array}$ & $\begin{array}{c}\mathrm{C} / \mathrm{N} \\
(\%)\end{array}$ & $\begin{array}{c}\text { P-total } \\
(\%)\end{array}$ & $\begin{array}{c}\text { K-total } \\
(\%)\end{array}$ \\
\hline 1 & Kontrol 1 & $8.00 \mathrm{~g}$ & $0.82 \mathrm{ab}$ & $0.47 \mathrm{a}$ & $0.05 \mathrm{a}$ & $11 \mathrm{~b}$ & $0.003 \mathrm{a}$ & $1.07 \mathrm{e}$ \\
2 & Kontrol 2 & $8.00 \mathrm{~g}$ & $0.49 \mathrm{a}$ & $0.30 \mathrm{a}$ & $0.05 \mathrm{a}$ & $5 \mathrm{a}$ & $0.005 \mathrm{bc}$ & $0.79 \mathrm{bc}$ \\
3 & A1 & $7.40 \mathrm{f}$ & $0.69 \mathrm{ab}$ & $0.40 \mathrm{a}$ & $0.09 \mathrm{a}$ & $5 \mathrm{a}$ & $0.004 \mathrm{ab}$ & $0.75 \mathrm{ab}$ \\
4 & $\mathrm{~A} 2$ & $7.20 \mathrm{ef}$ & $1.02 \mathrm{~b}$ & $0.46 \mathrm{a}$ & $0.11 \mathrm{a}$ & $4 \mathrm{a}$ & $0.003 \mathrm{a}$ & $0.68 \mathrm{a}$ \\
5 & $\mathrm{~B} 1$ & $6.47 \mathrm{c}$ & $2.38 \mathrm{de}$ & $1.37 \mathrm{~cd}$ & $0.41 \mathrm{de}$ & $4 \mathrm{a}$ & $0.004 \mathrm{ab}$ & $0.86 \mathrm{~cd}$ \\
6 & $\mathrm{~B} 2$ & $5.67 \mathrm{~b}$ & $2.62 \mathrm{e}$ & $1.45 \mathrm{~cd}$ & $0.38 \mathrm{~cd}$ & $4 \mathrm{a}$ & $0.005 \mathrm{bc}$ & $0.71 \mathrm{a}$ \\
7 & $\mathrm{C} 1$ & $6.93 \mathrm{de}$ & $1.76 \mathrm{c}$ & $0.92 \mathrm{~b}$ & $0.20 \mathrm{~b}$ & $4 \mathrm{a}$ & $0.015 \mathrm{f}$ & $0.83 \mathrm{bcd}$ \\
8 & $\mathrm{C} 2$ & $5.63 \mathrm{~b}$ & $2.32 \mathrm{de}$ & $1.33 \mathrm{~cd}$ & $0.40 \mathrm{de}$ & $3 \mathrm{a}$ & $0.007 \mathrm{e}$ & $0.84 \mathrm{~cd}$ \\
9 & $\mathrm{D} 1$ & $6.73 \mathrm{~cd}$ & $2.20 \mathrm{~d}$ & $1.25 \mathrm{c}$ & $0.37 \mathrm{~cd}$ & $4 \mathrm{a}$ & $0.017 \mathrm{~g}$ & $0.84 \mathrm{~cd}$ \\
10 & $\mathrm{D} 2$ & $6.83 \mathrm{~d}$ & $2.41 \mathrm{de}$ & $1.37 \mathrm{~cd}$ & $0.31 \mathrm{c}$ & $4 \mathrm{a}$ & $0.007 \mathrm{e}$ & $0.89 \mathrm{~d}$ \\
11 & $\mathrm{E} 1$ & $5.17 \mathrm{a}$ & $3.14 \mathrm{f}$ & $1.82 \mathrm{e}$ & $0.48 \mathrm{f}$ & $4 \mathrm{a}$ & $0.006 \mathrm{~cd}$ & $0.87 \mathrm{~cd}$ \\
12 & $\mathrm{E} 2$ & $5.50 \mathrm{~b}$ & $2.66 \mathrm{e}$ & $1.54 \mathrm{~d}$ & $0.46 \mathrm{ef}$ & $4 \mathrm{a}$ & $0.007 \mathrm{de}$ & $0.83 \mathrm{bcd}$ \\
\hline
\end{tabular}

Keterangan: Angka yang diikuti dengan huruf yang sama pada kolom yang sama menujukkan perlakuan tidak berbeda nyata pada uji BNJ 5\%. Kode perlakuan dapat dilihat pada Tabel 1.

Perlakuan memberikan pengaruh yang nyata terhadap kadar bahan organik pada biourin berdasarkan uji ANOVA pada taraf $5 \%$. Kadar bahan organik tertinggi terdapat pada perlakuan E1 (30 ml pupuk hayati dan $750 \mathrm{ml}$ molase pada $10 \mathrm{~L}$ urin) dan berbeda nyata berdasarkan uji BNJ 5\% bila dibandingkan dengan perlakuan lain. Tingginya kadar bahan organik pada perlakuan E1 diduga dipengaruhi oleh penambahan molase. Tingginya bahan organik akan dapat meningkatkan kulitas pupuk yang dihasilkan. Penambahan molase yang mengandung bahan organik dapat meningkatkan kualitas pupuk. Meskipun demikian, Kandungan kimia biourin (kecuali $\mathrm{pH})$ setiap perlakuan pada hari ke-28 dekomposisi belum memenuhi standar minimal pupuk organik cair.

\section{Pengaruh Perlakuan terhadap Karakteristik Fisik Biourin}

Hasil pengamatan terhadap karakteristik fisik biourin menunjukkan adanya perbedaan warna dan aroma (Tabel 5). Warna yang dihasilkan oleh biourin beragam, dari yang berwarna cokelat kehitaman hingga cokelat kekuningan. Hal ini dipengaruhi oleh bahan yang digunakan dalam pembuatan biourin. Biourin yang ditambah dengan molase memiliki warna yang hitam pekat sedangkan empon-empon menghasilkan warna jingga.
Harahap (2003) menyatakan bahwa warna cokelat kemerahan pada molase disebabkan adanya pigmen meladonin, degradasi thermal dan kimiawi dari komponen selain gula.

Aroma merupakan faktor penting dalam menentukan tingkat kematangan biourin dalam proses dekomposisi. Dekomposisi dilakukan untuk menghilangkan amonia. Rizki et al. (2015) menyatakan bahwa proses dekomposisi dapat menghilangkan senyawa amonia yang terbentuk dari nitrogen di dalam urin sapi. Bau amonia pada perlakuan kontrol masih sangat tajam, hal ini dikarenakan pada perlakuan tersebut tidak ada tambahan pupuk hayati, empon-empon ataupun molase yang membantu proses dekomposisi. Rata-rata perlakuan yang ditambahkan empon-empon tidak berbau sedangkan yang tidak diberikan empon-empon aroma amonianya cukup menyengat. Hartiati (2003); Gholib dan Darmono (2008); serta Nurhasanah et al. (2011) menyatakan bahwa rimpang kunyit, lengkuas dan kencur mengandung minyak atsiri, sehingga dapat mengurangi bau pada urin sapi yang didekomposisi. Bau pada perlakuan kontrol juga menunjukkan bahwa biourin belum matang. Menurut Purwendro dan Nurhidayat (2007), indikator keberhasilan pupuk organik cair adalah pupuk organik cair berwarna cokelat kekuningan dan tidak memiliki bau yang menyengat. 
Tabel 5. Warna dan aroma pada urin sapi setelah difermentasi 28 hari

\begin{tabular}{|c|c|c|c|c|c|c|c|}
\hline \multirow{2}{*}{ No } & \multirow{2}{*}{ Perlakuan } & \multicolumn{2}{|c|}{ Ulangan 1} & \multicolumn{2}{|c|}{ Ulangan 2} & \multicolumn{2}{|c|}{ Ulangan 3} \\
\hline & & Warna & Aroma & Warna & Aroma & Warna & Aroma \\
\hline 1 & & Cokelat & $\mathrm{Bau}$ & Cokelat & Bau Sedikit & & Bau Tidak \\
\hline 1 & & Kehitaman & Menyengat & Kehitaman & Menyengat & Cokelat & Menyengat \\
\hline 2 & Kontrol 2 & Cokelat & Tidak Bau & Cokelat & Agak Bau & Cokelat & Tidak Bau \\
\hline 3 & & Cokelat & $\mathrm{Bau}$ & Cokelat & $\mathrm{Bau}$ & Cokelat & $\mathrm{Bau}$ \\
\hline 3 & A & Kehitaman & Menyengat & Kehitaman & Menyengat & Kehitaman & Menyengat \\
\hline 4 & $\mathrm{~A} 2$ & Cokelat Tua & Tidak Bau & Cokelat Tua & Agak Bau & Cokelat Tua & Tidak Bau \\
\hline 5 & B1 & Cokelat & Agak Bau & Cokelat & Tidak Bau & $\begin{array}{l}\text { Cokelat } \\
\text { Kehijauan }\end{array}$ & Tidak Bau \\
\hline 6 & B2 & $\begin{array}{c}\text { Cokelat } \\
\text { Kehijauan }\end{array}$ & Agak Bau & $\begin{array}{c}\text { Cokelat } \\
\text { Kekuningan }\end{array}$ & Agak Bau & Cokelat Tua & Berbau \\
\hline 7 & $\mathrm{C} 1$ & $\begin{array}{c}\text { Cokelat } \\
\text { Kekuningan }\end{array}$ & $\begin{array}{l}\text { Bau Agak } \\
\text { Menyengat }\end{array}$ & Cokelat Tua & $\begin{array}{l}\text { Berbau } \\
\text { Menyengat }\end{array}$ & $\begin{array}{l}\text { Cokelat } \\
\text { Kehitaman }\end{array}$ & $\begin{array}{l}\text { Bau Agak } \\
\text { Menyengat }\end{array}$ \\
\hline 8 & $\mathrm{C} 2$ & $\begin{array}{c}\text { Cokelat } \\
\text { Kekuningan }\end{array}$ & $\begin{array}{l}\text { Agak } \\
\text { Berbau }\end{array}$ & Cokelat & $\begin{array}{l}\text { Agak } \\
\text { Berbau }\end{array}$ & $\begin{array}{l}\text { Cokelat } \\
\text { Terang }\end{array}$ & $\begin{array}{l}\text { Tidak } \\
\text { Berbau }\end{array}$ \\
\hline 9 & D1 & $\begin{array}{l}\text { Cokelat } \\
\text { Kekuningan }\end{array}$ & $\begin{array}{l}\text { Bau Agak } \\
\text { Menyengat }\end{array}$ & Cokelat & $\begin{array}{l}\text { Berbau } \\
\text { Menyengat }\end{array}$ & Cokelat & $\begin{array}{l}\text { Berbau } \\
\text { Menyengat }\end{array}$ \\
\hline 10 & D2 & $\begin{array}{l}\text { Cokelat } \\
\text { Kehitaman }\end{array}$ & Tidak Bau & $\begin{array}{c}\text { Cokelat } \\
\text { Kehitaman }\end{array}$ & Tidak Bau & $\begin{array}{c}\text { Cokelat } \\
\text { Kehitaman }\end{array}$ & Agak Bau \\
\hline 11 & E1 & Cokelat Tua & Tidak Bau & Cokelat Tua & Tidak Bau & Cokelat Tua & Agak Bau \\
\hline 12 & E2 & Cokelat Tua & Agak Bau & Cokelat Tua & Tidak Bau & $\begin{array}{c}\text { Cokelat } \\
\text { Kekuningan }\end{array}$ & Tidak Bau \\
\hline
\end{tabular}

\section{Pengaruh Perlakuan terhadap Populasi Mikroba pada Biourin}

Hasil penelitian menunjukkan penambahan molase, pupuk hayati, dan empon-empon pada biurin memberikan pengaruh yang berbeda terhadap populasi mikroba. Populasi mikroba terbanyak terdapat pada perlakuan E2 (30 $\mathrm{ml}$ pupuk hayati +750 $\mathrm{ml}$ molase $+500 \mathrm{~g}$ empon-empon dalam $10 \mathrm{~L}$ urin), sedangkan terendah pada kontrol 2 (empon-empon dalam $10 \mathrm{~L}$ urin sapi) (Tabel 4). Populasi tertinggi pada perlakuan E2 disebabkan karena dosis pupuk hayati, molase dan empon-empon yang diberikan mengandung mikroba, sehingga jika dikombinasikan dengan konsentrasi yang tinggi maka akan meningkatkan populasi mikroba. Rendahnya populasi Mikroba pada Kontrol 2 (penambahan empon-empon $500 \mathrm{~g}$ ) diduga karena pada perlakuan tersebut tidak ada penambahan molase yang merupakan sumber energi untuk mikroba sehingga populasi mikroba sedikit.

Hasil pengamatan menujukkan jumlah mikroba yang berpotensi membawa penyakit (E. coli dan Salmonella sp) pada masingmasing perlakuan memiliki populasi yang berbeda. Perlakuan dengan kontaminan tertinggi terdapat pada kontrol 1 dan terendah pada E2 $(30 \mathrm{ml}+750 \mathrm{ml}$ molase $+500 \mathrm{~g}$ empon-empon dalam $10 \mathrm{~L}$ urin). Populasi bakteri E. coli dan Salmonella sp menurut standart kualitas pupuk organik cair masih termasuk pada batas aman karena tidak lebih dari $10^{2} \mathrm{cfu} / \mathrm{ml}$, namun termasuk pada kriteria maksimal. Jumlah kedua bakteri tersebut pada beberapa perlakuan mengalami penurunan dibandingkan analisa awal. Penurunan populasi tersebut diduga karena adanya proses dekomposisi dan penambahan empon-empon yang memiliki kandungan antimikroba.

\section{Pengaruh Biourin terhadap Pertumbuhan Pakchoy}

Hasil penelitian menunjukkan pengaplikasian biourin pada tanaman pakchoy memberikan pengaruh yang nyata terhadap berat basah, tetapi tidak memberikan pengaruh yang nyata pada jumlah daun.

Perlakuan P5 (dosis $600 \mathrm{ml}$ biourin/ tanaman) memberikan hasil yang terbaik pada tanaman pakchoy bila dibandingkan dengan kontrol. Pada 14 HST pemberian biourin sapi mampu meningkatkan jumlah daun pakchoy sebanyak $42 \%$, sedangkan pada 21 HST jumlah daun meningkat $33 \%$ bila dibandingkan kontrol (tanpa pemberian biourin). Hasil penelitian Murtryarny et al. (2014) menunjukkan, pemberian biourin kelinci sebanyak $100 \%$ dapat meningkatkan jumlah daun pada tanaman pakchoy sebanyak $70 \%$ bila dibandingkan tanpa pemberian 
biourin kelinci, sedangkan pada penelitian Rizki et al. (2014), pemberian biourin sebanyak $400 \mathrm{ml}$ per liter air dapat meningkatkan jumlah daun sebanyak $78 \%$ dibandingkan tanpa pemberian biourin sapi. Penelitian lain yang dilakukan oleh Nathania (2012) menunjukkan pemberian biourin dengan konsentrasi $300 \quad \mathrm{ml} / \mathrm{l}$ mampu memingkatkan jumlah daun hingga 9 helai. Peningkatan daun disebabkan, urin sapi mengandung beberapa unsur yang diperlukan oleh tanaman untuk proses pertumbuhan seperti, nitrogen, fosfor, kalium, carbon, air, dan fitohormon auksin, sehingga dapat meningkatkan jumlah daun tanaman pakchoy (Oka, 2014).

Aplikasi biourin memberikan pengaruh yang nyata terhadap bobot basah tanaman pakchoy. Perlakuan terbaik yaitu P5 (dosis 600 $\mathrm{ml}$ biourin) mampu meningkatkan berat basah tanaman pakchoy menjadi $26.06 \mathrm{~g} /$ tanaman atau meningkatkan sebanyak $405 \%$ dibandingkan tanpa pemberian biourin. Hasil ini sesuai dengan penelitian yang dilakukan oleh Rizki et al. (2014), bahwa pemberian dosis pupuk $400 \mathrm{ml}$ per liter air dapat meningkatkan jumlah bobot basah tanaman sawi hijau sebanyak 380\% dibandingkan tanpa pemberian biourin sapi. Peningkatan bobot basah tanaman dapat mencapai hasil yang optimal karena tanaman memperoleh hara dengan cukup, sehingga peningkatan jumlah maupun ukuran sel dapat mencapai optimal serta memungkinkan adanya peningkatan kandungan air tanaman (Arinog dan Chrispen, 2011).

Tabel 6. Pengaruh perlakuan terhadap populasi mikroba dan E. coli serta Salmonella sp pada biourin

\begin{tabular}{|c|c|c|c|c|}
\hline No & Perlakuan & $\begin{array}{l}\text { Populasi Mikroba } \\
\text { (cfu/ml) }\end{array}$ & $\begin{array}{l}\text { E. coli } \\
\text { (cfu/ml) }\end{array}$ & $\begin{array}{l}\text { Salmonella } s p . \\
\quad(\mathrm{cfu} / \mathrm{ml})\end{array}$ \\
\hline 1. & Kontrol 1 & $26 \times 10^{2(R)}$ & $47 \times 10^{4(\mathrm{R})}$ & $98 \times 10^{3(\mathrm{R})}$ \\
\hline 2. & Kontrol 2 & $15 \times 10^{2}(\mathrm{R})$ & $71 \times 10^{3}(\mathrm{R})$ & $60 \times 10^{3}(\mathrm{R})$ \\
\hline 3. & A1 & $19 \times 10^{3}(\mathrm{R})$ & $17 \times 10^{3}(\mathrm{R})$ & $30 \times 10^{2(\mathrm{~K})}$ \\
\hline 4. & $\mathrm{~A} 2$ & $54 \times 10^{3(\mathrm{R})}$ & $12 \times 10^{3(\mathrm{R})}$ & $23 \times 10^{2(\mathrm{R})}$ \\
\hline 5. & B1 & $13 \times 10^{4(\mathrm{R})}$ & $11 \times 10^{3(\mathrm{R})}$ & $19 \times 10^{2(\mathrm{R})}$ \\
\hline 6. & B2 & $30 \times 10^{5(\mathrm{R})}$ & $37 \times 10^{3(\mathrm{R})}$ & $15 \times 10^{3(\mathrm{R})}$ \\
\hline 7. & $\mathrm{C} 1$ & $75 \times 10^{3(\mathrm{R})}$ & $48 \times 10^{2(\mathrm{~K})}$ & $31 \times 10^{2(\mathrm{~K})}$ \\
\hline 8. & $\mathrm{C} 2$ & $10 \times 10^{4(\mathrm{R})}$ & $26 \times 10^{3}(\mathrm{R})$ & $54 \times 10^{2(\mathrm{R})}$ \\
\hline 9. & D1 & $32 \times 10^{4(\mathrm{R})}$ & $77 \times 10^{2(\mathrm{R})}$ & $10 \times 10^{2(\mathrm{R})}$ \\
\hline 10. & D2 & $16 \times 10^{4(\mathrm{R})}$ & $32 \times 10^{2(\mathrm{~K})}$ & $63 \times 10^{1(\mathrm{~K})}$ \\
\hline 11. & E1 & $32 \times 10^{5(\mathrm{R})}$ & $15 \times 10^{2(\mathrm{R})}$ & $58 \times 10^{1(\mathrm{~K})}$ \\
\hline 12. & E2 & $25 \times 10^{6(\mathrm{R})}$ & $43 \times 10^{2(\mathrm{R})}$ & $20 \times 10^{2(\mathrm{~K})}$ \\
\hline
\end{tabular}

Keterangan: (R) Rendah. Sumber Kriteria Balittan (2009).

Tabel 7. Jumlah daun dan berat basah pakchoy

\begin{tabular}{|c|c|c|c|c|c|c|c|}
\hline \multirow{2}{*}{ No } & \multirow{2}{*}{ Perlakuan } & \multicolumn{5}{|c|}{ Jumlah Daun (Helai) } & \multirow{2}{*}{$\begin{array}{l}\text { Bobot Basah } \\
\text { (g/tanaman) }\end{array}$} \\
\hline & & $0 \mathrm{HST}$ & $7 \mathrm{HST}$ & $14 \mathrm{HST}$ & $21 \mathrm{HST}$ & $28 \mathrm{HST}$ & \\
\hline 1 & P0 & 3.3 & 4.0 & $4.7 \mathrm{a}$ & $6.0 \mathrm{ab}$ & $6.3 \mathrm{a}$ & $5.16 \mathrm{a}$ \\
\hline 2 & P1 & 3.7 & 4.3 & $5.3 \mathrm{ab}$ & $5.7 \mathrm{a}$ & $6.7 \mathrm{ab}$ & $7.54 \mathrm{~b}$ \\
\hline 3 & P2 & 3.3 & 4.3 & $5.0 \mathrm{ab}$ & $6.7 \mathrm{abc}$ & $8.0 \mathrm{bc}$ & $11.47 \mathrm{c}$ \\
\hline 4 & P3 & 4.0 & 4.7 & $6.3 \mathrm{ab}$ & $7.3 \mathrm{abc}$ & $9.0 \mathrm{c}$ & $18.70 \mathrm{~d}$ \\
\hline 5 & P4 & 3.3 & 4.7 & $6.3 \mathrm{ab}$ & 7.7 bc & $8.7 \mathrm{c}$ & $20.86 \mathrm{~d}$ \\
\hline 6 & P5 & 3.07 & 5.0 & $6.7 \mathrm{~b}$ & $8.0 \mathrm{c}$ & $9.3 \mathrm{c}$ & $26.06 \mathrm{e}$ \\
\hline
\end{tabular}

Keterangan: HST= hari setelah tanam. Huruf yang sama pada kolom yang sama menujukkan perlakuan tidak berbeda nyata berdasarkan uji BNJ 5\%.

\section{KESIMPULAN}

Penggunaan biourin sapi yang diperkaya dengan pupuk hayati dengan mikroba sebanyak $30 \mathrm{ml}$, dan molase $750 \mathrm{ml}$ pada $10 \mathrm{~L}$ urin mampu meningkatkan $\mathrm{N}$-total $860 \%$, bahan organik $282 \%$, dan populasi mikroba sebesar $1229 \%$. Biourin (perlakuan 
E1) yang diaplikasikan pada tanaman pakchoy dengan dosis $600 \mathrm{ml} \mathrm{L} \mathrm{L}^{-1} / \operatorname{tanaman}$ dapat meningkatkan jumlah daun sebesar $48 \%$ dan bobot basah $405 \%$ jika dibandingkan tanpa pemberian biourin.

\section{UCAPAN TERIMA KASIH}

Penulis mengucapkan terima kasih kepada Fakultas Pertanian Universitas Brawijaya yang telah memberi dukungan finansial terhadap penelitian ini.

\section{DAFTAR PUSTAKA}

Aisyah, S., N. Sunarlim, B. Solfan. 2011. Pengaruh urine sapi terfermentasi dengan dosis dan interval pemberian yang berbeda terhadap pertumbuhan tanaman sawi (Brassica juncea L.). Jurnal Agroteknologi. 2(1): 1-5.

Arinong, A.R., C.D. Lasiwua. 2011. Aplikasi pupuk organik cair terhadap pertumbuhan dan produksi tanaman sawi. Jurnal Agrisistem. 7(1): 47-54.

[Balittan] Balai Penelitian Tanah. 2009. Petunjuk teknis analisis kimia, tanah, tanaman, air dan pupuk. Balai Besar Litbang Sumberdaya Lahan Pertanian. Balai Penelitian dan Pengembangan Pertanian. Departemen Pertanian. Bogor.

Gholib, D., Darmono. 2008. Pengaruh ekstrak lengkuas putih (Alpinia galanga (L.) Willd) terhadap infeksi Trichophyton mentagrophytes pada kelinci. Jurnal Ilmu Kefarmasian Indonesia. 6(2): 5762.

Harahap, H. 2003. Karya ilmiah produksi alkohol. Program Studi Teknik Kimia Fakultas Teknik, Universitas Sumatera Utara.

Hartiati, S.Y. 2013. Khasiat kunyit sebagai obat tradisional dan manfaat lainnya. Warta Penelitian dan Pengembangan Tanaman Industri. 19(2): 5-9.
Haryanto, E., T. Suhartini, E. Rahayu, H.H Sunarjono. Sawi dan Selada. 2007. Cetakan 11. Penebar Swadaya, Jakarta.

Indriani, Y.H. 2011. Membuat Kompos Secara Kilat. Penebar Swadaya. Jakarta.

Kartika, J.G., K. Suketi, N. Mayasari. 2016. Produksi biomassa dan minyak atsiri kemangi (Ocimum basilicum L.) pada berbagai dosis pupuk nitrogen dan pupuk cair hayati. J. Hort. Indonesia. 7(1): 56-62.

Kurniadinata, O.F. 2007. Pemanfaatan feses urin sapi sebagai pupuk organik dalam perkebunan kelapa sawit. Seminar Optimalisasi Hasil Samping Perkebunan Kelapa Sawit dan Industri Olahannya sebagai Pakan Ternak. Paser, Kalimantan Timur. Juli 2007: 65-72.

Mutriyarny, E., Endriani, U. Lestari. 2014 Pemanfaatan urine kelinci untuk meningkatkan pertumbuhan dan produksi tanaman sawi (Brassica juncea L) varietas Tosakan. Jurnal Ilmiah Pertanian. 11(2): 23-34.

Nathania, B., I.M. Sukewijaya, N.W.S. Sutari 2012. Pengaruh aplikasi biourin gajah terhadap pertumbuhan dan hasil tanaman sawi hijau (Brassica juncea L.). E-Jurnal Agroekoteknologi Tropika. 1(1): 72-85.

Nurawaliah, S. 2014. Pemanfaatan ampas penyulingan daun nilam sebagai bahan litter pada pemeliharaan ayam broiler. Prosiding Seminar Nasional "Inovasi Teknologi Pertanian Spesifik Lokasi", Banjarbaru 6-7 Agustus 2014: 587-593.

Nurhasanah, A.N., F. Nazaruddin, E. Febriana, A. Zuhrotun. 2011. Analisis kandungan minyak atsiri dan uji aktivitas antiinflamasi ekstrak rimpang kencur (Kaempferia galanga L.). Jurnal Matematika dan Sains. 16(3): 147-152.

Ohorella, Z. 2012. Pengaruh dosis pupuk organik cair (POC) kotoran sapi terhadap pertumbuhan dan produksi tanaman sawi hijau (Brassica sinensis L.). Jurnal Agroforestri. 7(1): 43-49. 
Oka, D.N. 2014. Urine sapi meningkatkan produksi tanaman sawi hijau (Brassica juncea L.) dan implementasinya pada pembelajaran hortikultura. Suluh Pendidikan. 12(2): 113-122.

Perdana, S.N., W.S. Dwi, M. Santoso. 2015. Pengaruh aplikasi biourin dan pupuk terhadap pertumbuhan dan hasil tanaman bawang merah (Allium ascalonicum L.). J. Prod. Tan. 3(6): 457-463.

Purwendro, D., T. Nurhidayat. 2007. Pembuatan Pupuk Cair. PT Gramedia Pustaka Utama. Jakarta.

Rinekso, K.B., E. Sutrisno, S. Sumiyati. 2011. Studi pembuatan pupuk organik cair dari fermentasi urine sapi (Ferisa) dengan variasi lokasi peternakan yang berbeda. Program Studi Teknik Lingkungan, Fakultas Teknik, Universitas Diponegoro, Semarang.

Rizki, K., A. Rasyad, Murniati. 2014. Pengaruh pemberian urin sapi yang difermentasi terhadap pertumbuhan dan produksi tanaman sawi hijau (Brassica rafa). Jurnal Pertanian. 1(2): 1-8.

Sufianto. 2014. Analisis mikroba pada cairan sebagai pupuk cair limbah organik dan aplikasinya terhadap tanaman pakcoy (Brassica chinensis L.). Jurnal Gama. 9(2): 77-94.

Tandi, O.G., J. Paulus, A. Pinaria. 2015. Pertumbuhan dan produksi bawang merah (Allium ascalonicum L.) berbasis aplikasi biourin sapi. Jurnal Eugenia. 21(3): 142-150. 